Do Global Firms Measure Expatriate Return on Investment?

An Empirical Examination of Measures, Barriers and Variables Influencing Global Staffing Practices

Yvonne McNulty ${ }^{1}$, Helen De Cieri, and Kate Hutchings

Department of Management, Faculty of Business and Economics, Monash University,

PO Box 197, East Caulfield VIC 3145 AUSTRALIA

\footnotetext{
${ }^{1}$ Corresponding author. Email: Yvonne.mcnulty@buseco.monash.edu.au
} 


\title{
Do Global Firms Measure Expatriate Return on Investment? An Empirical Examination of Measures, Barriers and Variables Influencing Global Staffing Practices
}

\begin{abstract}
Many managers in global firms regard the ability to obtain a return on investment (ROI) from expatriates as important, given the substantial costs associated with global staffing practices, particularly international assignments, and the risks and uncertainties of deploying key talent. This research examines how expatriate ROI is measured for longterm assignments in 51 global firms, across 18 industries, and with headquarters in North America, UK, Europe, Africa, and Asia Pacific. Our findings suggest that firms do not have formal procedures in place to measure expatriate ROI and instead rely heavily on informal practices that are seldom aligned to a global strategy. Cultural, operational, and strategic barriers to measuring ROI also exist. In addition, we are challenged to consider whether measuring expatriate ROI is actually a goal for managers in global firms, given the evidence which suggests that for some firms having expatriates is often a cost of doing business for which a formal measure may be unnecessary. An alternative view suggests that if international assignments are considered a necessary cost of doing business for global firms, how expatriates are managed in terms of the HR practices that support their activities and how the outcomes of those activities impact broader firm performance may be far more important concerns. Based on evidence that the nature of expatriation is rapidly changing, we conclude that expatriate ROI remains a challenging and complex process that managers in global firms are currently not well-equipped to address. The findings have important implications for the planning and management of international assignments.
\end{abstract}

Keywords: expatriates; HRM strategies and practices; return on investment; qualitative research methods

\section{Introduction}

Utilizing expatriates is an important dimension of global staffing in many firms, given the internationalization of markets, competition and technology (Shaffer, Harrison, Gregersen, Black, \& Ferzandi, 2006). Employing expatriates can be a cost of doing business for firms that compete globally (Scullion \& Collings, 2006). As such, an important goal for global managers may be to obtain an acceptable return on investment (ROI) from expatriates (relative to the costs and value of employing local staff) as one of several HR and non-HR measures that may be used to evaluate the effective management of international assignments and expatriate careers. Other measures may include how global staffing practices contribute to effective productivity, financial performance, and competitive 
advantage (Bowen \& Ostroff, 2004), and how sets of HR practices such as high performance work systems (HPWS) (Huselid, 1995) can facilitate the achievement of a firm's strategic goals (Toh, Morgeson, \& Campion, 2008). Likewise, expatriates may also seek individual returns for both personal and career development reasons as a way to improve their 'career capital' (Dickmann \& Harris, 2005). Whilst recognizing that the sustainability of HRM - to seek benefits for individuals, organizations and society - must consider the perspectives of multiple stakeholders and not just that of the employer (Beer, Spector, Lawrence, Mills, \& Walton, 1984), the focus of this paper broadens our understanding of expatriate ROI from a management perspective.

Global staffing has become a significant challenge for firms, not only in terms of financial costs but also in strategic terms (Scullion \& Collings, 2006). Over the past decade, a growing literature on strategic and international human resource management (IHRM) has attempted to address this challenge by emphasizing the importance of linking HR activities to global strategies to improve business performance (De Cieri \& Dowling, 2006). Within this literature, researchers have identified organizational and individual practices that can help firms achieve international assignment success, such as selection (Collings, Scullion, \& Morley, 2007), repatriation (Lazarova \& Cerdin, 2007), retention (Suutari \& Brewster, 2003), expatriate adjustment (Bhaskar-Shrinivas, Harrison, Shaffer, \& Luk, 2005) and personality characteristics (Shaffer et al., 2006).

Despite the proliferation of a substantive literature on IHRM, managers in global firms still seem to have difficulty determining what constitutes an acceptable ROI from expatriates (Black, Gregersen, Mendenhall, \& Stroh, 1999). Explanations offered by scholars for these difficulties range from ineffective decision frameworks that can hinder the development of effective measures which are linked to planning activities (such as global staffing decisions) (Boudreau \& Ramstad, 2007), and failure to plan at the operational level to measure international assignee performance and its subsequent contribution to the bottom line (Scullion \& Collings, 2006). Consequently, and in spite of the anecdotal and practitioner evidence that there are important reasons to obtain an ROI from long-term assignments, current understanding of expatriate ROI appears limited and research in this field is still in its infancy (cf. McNulty \& Tharenou, 2004; Schmidt \& Minssen, 2007). 
One important reason for examining expatriate ROI is the costs associated with global staffing decisions, and in particular long-term assignments. Financial costs can account for as much as 5 or 6 percent of total headcount costs in a global firm (ECA International, 2007). Non-financial costs, particularly when assignments fail, can include loss of intellectual knowledge and disruption to global leadership due to labor turnover, poor cross-cultural adjustment leading to poor performance, and disrupted relationships with host country nationals (Bhaskar-Shrinivas et al., 2005; Suutari \& Brewster, 2003). Costs to the expatriate may include relationship difficulties and other stresses, decreased commitment, and weakening of the psychological contract (Takeuchi, Wang, \& Marinova, 2005). Despite these costs and reports that firms are attempting to reduce global staffing and international assignment expenses (GMAC, 2005), many continue to use long-term expatriates as a source of value creation even when cost-effective alternatives are available (Collings et al., 2007).

An additional reason for undertaking research on expatriate ROI is that much of the previous research into global staffing, international assignments, and expatriation has adopted only a micro-level perspective, in terms of investigating single HR practices such as selection, training and development, and repatriation independent of any other HR practices that may also impact global staffing decisions and consequences (cf. Wright \& Boswell, 2002). Studies in three key areas have examined only individual measures of assignment success and failure rather than the costs and benefits associated with expatriate ROI: (1) expatriates’ premature return from an assignment (Takeuchi, Yun, \& Tesluk, 2002); (2) labour turnover rates from repatriation (Suutari \& Brewster, 2003); and (3) expatriate job performance (Caliguiri \& Day, 2000). Although informative, this research stream has largely ignored a HR systems approach to the costs and benefits of international assignments, in terms of the collective impact of a range of possible variables that may influence expatriate behaviour and, in turn, broader firm performance (Ostroff, 2000; Wright \& Haggerty, 2004).

One aim of our research is to extend the focus of expatriate ROI for long-term assignments, defined as the relocation of an employee abroad by a firm for a year or more (GMAC, 2005), beyond individual practices and outcomes to utilize a HR systems approach. Our research is salient in moving beyond the micro-level focus of previous studies, to take into account the short and long-term costs and benefits of 
the range of HR activities occurring during long-term assignments that may subsequently influence the effective management of international assignments and expatriate careers. An additional aim of our research is to extend our understanding of expatriate ROI in global firms by examining how ROI is measured and the barriers that may impede measurement. Our intention is to move beyond the conclusion that managers in global firms may have difficulty measuring expatriate ROI, to also explain why this may be so. Finally, we seek to identify important variables likely to influence changes in ROI to the firm in order to understand the link between how expatriates are managed (in terms of the HR practices that support their activities) and how the outcomes of those activities impact expatriate ROI, and in turn, broader firm performance.

\section{Conceptual foundations of expatriate ROI}

In this paper, we use McNulty and Tharenou’s definition of expatriate ROI: ‘a calculation in which the financial and non-financial benefits to the firm are compared with the financial and non-financial costs of the international assignment, as appropriate to the assignment’s purpose’ (2004: 73). Importantly, the definition is concerned with whether the benefit to the firm outweighs the costs of the international assignment, irrespective of whether a cost is financial (e.g. cross-cultural training) and its corresponding benefit is non-financial (e.g. improved performance). The challenge in defining expatriate ROI is in linking the purpose of a global staffing decision to a firm's overall global strategy: managers must know the intent in order to track appropriate costs and benefits. Classifying expatriates according to their purpose has far-reaching implications for calculating expatriate ROI. For example, differences in purpose automatically negates the usefulness of a 'one best' ROI formula or measure that expects identical costs and benefits to be calculated for every assignment. Similarly, the purpose of the assignment determines the most appropriate time to perform an ROI calculation (e.g. at the point of repatriation or some years later). Additionally, many of the costs and benefits associated with long-term expatriates are often non-financial in nature and may not appear until years later, thus length of assignment is important. Misleading ROI calculations are more likely to result when longer-term perspectives with regard to an assignment's purpose are over-looked. 
McNulty \& Tharenou (2004) suggest nine major HR practices that take place during a long-term assignment with the potential to influence changes in expatriate ROI: (1) planning the assignment; (2) selection and recruitment; (3) outsourcing relocation administration; (4) compensation; (5) training and development; (6) non-work and family support; (7) performance management; (8) repatriation; and (9) retention. These HR practices are adapted in this research as a system of activities likely to have an impact on performance outcomes expected from expatriate ROI, rather than as individual, isolated activities. The distinction is important because even though these practices are well established independently in the literature, how they inter-relate to influence organizational effectiveness (e.g. a successful international assignment) is poorly understood (Becker \& Gerhart, 1996; Bowen \& Ostroff, 2004)

\section{HR systems approach}

In terms of measuring expatriate ROI, the HR systems approach has received widespread support in the HRM literature (cf. Becker \& Gerhart, 1996; Bowen \& Ostroff, 2004; Russ-Eft \& Preskill, 2005; Wright \& Boswell, 2002) and is particularly useful for explaining the manner in which ROI calculations can be made. General systems thinking views the firm as a complex collection of subsystems that interact with each other to produce an outcome (Kast \& Rosenzweig, 1973). We argue that an HR department (or a mobility unit) is one such subsystem in which HR practices and processes interact with one another internally, but also as a system with other processes (subsystems) external to the HR department such as consulting, sales, and research and development systems, to influence wider firm performance outcomes. To be effective, systems thinking requires a thorough understanding of internal and external fit at multiple levels in order to positively influence performance outcomes, i.e. it requires that HR systems, and operating and strategic objectives, are aligned and draw upon components at both the organizational and individual level of analysis (Becker \& Gerhart, 1996). The shared assumption amongst scholars (which we adopt) is that in order to truly examine the impact of HR practices on firm performance, one must examine the entire set of HR practices that exist (Wright \& Boswell, 2002; Toh et al., 2008).

An important benefit of the HR systems approach is that relationships between multiple variables can be established regardless of whether a variable has financial or non-financial and/or HR or non-HR 
characteristics (Wang, Dou, \& Li, 2002). The likely outcome is a framework that values long-term strategic gains and not just financial indicators of success. In addition, the HR systems approach enables an ROI calculation to be customized, and in so doing produce more accurate and relevant outcomes, because it recognizes that firms differ greatly in terms of industry, organizational culture and overall strategic objectives and that unique combinations of practices can more effectively account for these differences (Huselid, 1995). Furthermore, few studies have attempted to examine the 'black box' between a system of HR practices in expatriation and firm performance, where the impact of the effective management of international assignments and expatriate careers in practice may be one important aspect to consider. Importantly, if international assignments are viewed as a necessary cost of doing business for global firms, it is not the cost of sending an expatriate that matters most, but rather how expatriates are managed in terms of the HR practices that support their activities and how the outcomes of those activities can impact wider business objectives. Implications for firm performance includes not just the extent to which a satisfactory expatriate ROI can be obtained, but also whether human capital can be leveraged, discretionary behaviour increased, and a desired level of expatriate behaviours and attitudes achieved (Becker \& Gerhart, 1996).

In adopting the HR systems approach in this research, we also acknowledge criticisms which have focused on a lack of theoretical and methodological rigor in prior HR systems studies, including the mixed evidence to support the relationship between a firm's overall strategy, HR strategy, and firm performance (cf. Paauwe \& Boselie, 2005). Whilst Ostroff (2000) demonstrated support for the relationship, others have not had the same findings (Huselid, Jackson, \& Schuler, 1997; Rozhan, 1996). Therefore, in evaluating expatriate ROI we note that factors other than the strategic alignment of mobility to a firm's overall global strategy may account for performance outcomes. Paauwe (2004) suggests that culture, environmental, and institutional forces, as well as resource allocation, may influence firm-performance outcomes moreso than strategic alignment, whereas Bowen \& Ostroff (2004) argue that organizational climate may also be an important variable.

Building on earlier conceptual and empirical literature, in this research we address three key research questions: 
1. How is expatriate ROI for long-term assignments measured in global firms?

2. What barriers prevent expatriate ROI from being measured?

3. What are the variables influencing changes in the ROI of long-term assignments to the firm?

\section{Method}

This research involved semi-structured, in-depth interviews with 51 managers in global firms. The interview method was chosen to gather data because it is appropriate for acquiring an in-depth knowledge of complex issues and processes such as those found in strategic IHRM (Kiessling \& Harvey, 2005). A theoretical sample based on purposeful sampling was used (Creswell, 1998) and only firms with global operations employing expatriates were chosen. Interviewees were managers who work directly with expatriates or manage mobility programs; all could be expected to be well-informed about expatriate management and issues related to expatriate ROI.

We sourced 35 percent of managers via Organizational Resource Counselors (ORC), an IHRM consulting firm based in the USA, and 65 percent from the first author's professional network as an insider within the expatriate and mobility community. Respondents self-selected their participation based on a detailed description of the research provided in an introductory explanatory letter and consent form. Interview questions were developed from on extensive literature review based on a cross-discipline approach from the fields of accounting, economics, management and expatriation. Interviews (ranging in length from 45 minutes to two hours) were conducted over a two-year period from August 2004 to August 2006, mostly by phone (96\%) with the remainder (4\%) being face-to-face, to allow for time-zone and geographical differences. The cohort comprised 56 percent women and 44 percent men, with 51 percent either currently or previously undertaking some type of expatriate assignment (including longterm assignments). The majority of the 51 firms (63\%) are classified as a Fortune 500 company; these are very large, well-established firms that have utilized expatriates for a long time.

Assurances of confidentiality were given to the managers and pseudonyms are used throughout to ensure firms and managers cannot be identified. Eighty percent are public companies representing 18 different industries. The sample has extensive regional coverage with firm headquarters in North 
America, Europe, UK, Asia Pacific, and the Middle East/Africa. In total, the sample represents more than 52,000 long-term assignees. Table 1 provides background data on the 51 firms in the study.

[Table 1 about here]

We used computer-aided qualitative analysis software (NVIVO version 7), hierarchical categories to reduce, sort and cluster the data and then derive key themes (Denzin \& Lincoln, 2000), and content analysis to determine how strongly the themes are manifested (Miles \& Huberman, 1994). Although managers in this research provided a single-rater response, they can be viewed as expert informants. Problems associated with internal and external validity due to single-response bias and the first author's insider status within the expatriate and mobility community are addressed by using an inter-rater procedure (King, 1994). An independent researcher conducted a preliminary round of scoring of the categories, themes, and sub-themes on 10 randomly selected transcripts, giving an initial inter-rater reliability score of 93.5 percent based on an established formula (Goodwin \& Goodwin, 1985). After consultation and discussion, a second round of scoring resulted in a much higher score of 98.5 percent. The minimum acceptable inter-rater variation is 80 percent (Miles \& Huberman, 1994), which is consistent with the reliabilities we achieved.

\section{Findings}

\section{Expatriate ROI measures}

With regard to our first research question (how is expatriate ROI for long-term assignments measured in global firms?), none of the managers indicate they are using a formal ROI measure, preferring instead to use a range of informal 'success' measures. We categorize the informal ROI measures into five broad areas, shown in Table 2. The most common measure (41\%) is a short-term functional calculation in which the immediate benefits of the assignment are assessed in such areas as local objectives being met and percentage of premature returns/failures. Other measures include long-term strategic measures (31\%), financial measures (30\%), measures for approval purposes only (24\%), and individual measures of benefits accruing to the expatriate employee (12\%).

[Table 2 about here] 
An important finding in relation to this question is that none of the respondents indicated that they have been able to develop an ROI measure. Where informal measures are utilized, none of the measures calculate ROI in a meaningful way such that it adds value to the ongoing management of expatriates. In most firms, despite frequent use of a range of informal measures, the data required to calculate ROI do not seem to be consistently tracked or applied, nor routinely and appropriately aligned to a policy or mobility program, as a manager explains:

There's discussion that ROI is important. We kind of know things are going ok, but there's no formal process to measure it. How would you? And so that's usually as far as we get ...how [do] we actually operationalise those different processes to get it? There's always the 'ok, now what?' ... it's hard to figure out what the measures would be, it's not black and white enough to be able to say this is successful or not successful ... it takes a lot of work to get the organization to write things that are measurable.

AutomotiveCo2, North America, 1300 expatriates

In addition, some managers view expatriate ROI as unnecessary or inappropriate. This may be a valid view in some circumstances (and perhaps present some valid reasons why not to measure it); however, in many firms a lack of measurement may have negative outcomes. Thus, alternative views and barriers to measuring expatriate ROI remain an important issue.

\section{Barriers to measuring expatriate ROI}

In response to our second research question (what barriers prevent expatriate ROI from being measured?), three broad categories of barriers are identifiable in the data (see Table 3): cultural, operational, and strategic. Cultural barriers, which we define as organizational assumptions and values within the firm about the importance and relevance of expatriate ROI as a strategic tool, are cited most frequently (56\%). For many managers there is no buy-in or support as expatriates are seen as the cost of doing business; therefore, measurement of ROI is considered pointless because expatriates will still be used even if the return on investment is minimal. For others, international assignments are a necessary step for career development, so ROI is not seen as an important statistic which adds value, as one manager explains:

I think that relocations are kind of considered the cost of doing business, a necessary evil if you will, so I don't think that there's a lot of thought about the return on the investment ... I think it's an expectation that we have to send people to develop skills, so I don't think that there's as much of a concern about it ... there's nobody having to defend it. 
Operational barriers (44\%) are cited as typically being due to inefficiencies in day-to-day activities and processes. This category includes HR information systems (HRIS) that are inadequate or inappropriate for the task. Strategic barriers (30\%) refer to assignments that are poorly planned, resulting in a lack of accountability or ownership of mobility programs, including a lack of ownership for the development of appropriate measures to gauge the successful achievement of an assignment's intended objectives.

[Table 3 about here]

\section{Variables influencing changes in expatriate ROI}

In response to the third research question (what are the variables influencing changes in the ROI of longterm assignments to the firm?), we identified three broad categories of variables: environmental, individual, and organizational. All identified variables are listed in Table 4. Importantly, managers in the study confirm that whilst some variables impact on expatriate ROI more substantially than others and appear to act independently within a HR system, the cumulative effect of multiple variables (i.e. an interrelated system of HR practices) is a more likely explanation for changes in expatriate ROI than single variables in isolation. Thus, while we acknowledge the need to view HR practices as components within an integrated system (which data in our study confirm), in this section we highlight only two HR practices - planning and retention - which are identified by managers as representative of the independent and inter-dependent nature of all the variables likely to influence changes in expatriate ROI, as well as other organizational outcomes.

[Table 4 about here]

\section{Planning the assignment}

An important staffing goal for many firms is to increase international mobility opportunities for key employees in order to achieve broader business objectives, such as talent management and succession planning initiatives, and the longer-term retention of future organizational leaders. Yet managers express considerable concern about their ability to achieve these objectives when competing planning priorities exist. For example, localizing expatriates (transferring expatriates from expatriate benefits to local terms) 
and trimming benefits to reduce costs can often lead to the creation of additional longer-term problems such as reducing the attractiveness of international assignments or lowering cultural performance, as a manager explains:

I agree there are probably ways that we can do it less expensively, but no matter how much it costs, it's always going to be expensive, and when you look at $\$ 5,000$ for cultural training, we can cut $\$ 5,000$ out. But in a million dollar, three-year assignment, is that cost of $\$ 5,000$ to give someone cultural training so they can hit the ground running and really understand the mindset of the people they are working with, is that something that is really a wise saving? Penny wise and pound foolish comes to my mind.

FoodCo1, North America, 30 expatriates

An additional issue seems to be the lack of discipline surrounding why expatriates are used and then aligning their use to clearly defined assignment purposes. The problem almost always is the continued use of expatriates when they are not needed and the costs associated with these staffing decisions. Part of the problem lies in poor planning and selection procedures: if an expatriate has always done a particular job, no one questions that they will continue to do so. Thus, long-standing planning and selection practices that are no longer aligned to a broader strategy but remain in force because of factors such as company culture or a lack of support to change the status quo are cited by managers as significantly impacting global staffing decisions. Staffing decisions in turn can impact expatriate ROI, as one manager explains:

I can get their attention when I say why did you choose an expat for this position ... I say, they're three times as expensive; does this kind of expat do it three times faster than another - than a local? And they'll say ‘oh no, I don't think they can do it three times faster', and I'll say oh okay, they're going to do it three times better? And they say 'no, I don't think they can do it three times better', and I'll say, so what's the point? Why do you have this expat who's got to cost three times as much?

EnergyCo6, Europe, 7500 expatriates

\section{Retention}

Over 60 percent of respondents cite retention as an important variable because expatriates are viewed by managers as being neither easily replaced nor widely available in the external labour market, whose loss will incur heavy replacement costs. Our focus in examining retention is concerned with retaining expatriates both during and after an assignment. Importantly, our findings demonstrate that retention is a more frequently sought after goal for expatriated staff than repatriation given the rise in other global staffing activities such as re-assignment, inpatriation (transferring host-country and/or third-country 
nationals into the HQ of a firm on a semi to permanent basis), localization, and permanent mobility. Managers identify two challenges in successfully managing and retaining expatriates: localization, and local-plus compensation (a hybrid version of expatriate compensation with greatly reduced benefits). In both instances the firm's intention is to reduce overall mobility costs, resulting in a significant reduction in an expatriate's overall compensation. However, a reduction in compensation can then set in motion a desire (or need) for the expatriate to leave the firm and search for higher paying employment elsewhere, either in the current location or somewhere new, as a manager explains:

I've been pounded so much on cost ... we're being asked to reduce costs all the time, and it came to a point when I kept telling them that if you reduce costs we put all assignments at risk ... I've already lost three or four expatriates in China ... a couple of them are saying I'm retiring, but after they go they join another company in China ... these are senior level people that are probably being poached by other companies.

ConsumerCo4, Europe, 800 expatriates

To improve retention and the likelihood of achieving broader business objectives, some firms focus on improving pre-assignment planning by offering early-career expatriates a structured career path within the framework of a mobility program. The goal is to recruit only young, high potential employees and then reward and retain them with permanent mobility, extremely comprehensive financial packages and benefits, and the prestige of belonging to an exclusive group for which entry is extremely difficult. As a manager in the banking industry explains, the impact of this type of program on a firm's overall business growth and performance (in terms of ROI) can be significant:

Would the group be where it is today without our permanently mobile cadre? NO. We could not have had the growth that we've seen, where the expats have taken this organization where we couldn't have ... there's a strong belief that we need that IM [international mobility] cadre. They are the key differentiator and reason for our success ... the cadre is the glue or DNA of the organization ... so coming back to ROI, it would have to be substantial.

BankCo1, UK, 1800 expatriates

\section{Discussion}

Although the findings support the idea that having expatriates is a necessity in global firms and measuring expatriate ROI is a desired goal for many mobility managers, none of the participating firms formally measure expatriate ROI, due to perceived operational, cultural, and strategic barriers. The availability of appropriate data appears difficult to obtain and is too dependent on managers having the 
time, resources, top management support, and appropriate management software to calculate returns. When informal measures of ROI are used, they typically produce quantitative outcomes (e.g. turnover and promotion rates). Like Boudreau \& Ramstad (2007), we found that these data are seldom aligned to the original purpose of the assignment and consequently do not impact decisions in a way that can help managers sustain long-term strategic success. We also found minimal evidence that assignment costing data is tracked and utilized to assess quantitative (financial) rates of return, with even less evidence of non-financial data being used to monitor and assess assignee performance from a value-based perspective. As Scullion \& Collings (2006) note, if the tracking of financial costs and benefits is poor, then quantifying these costs and benefits in a meaningful way to determine a ROI will also be difficult, which our findings confirm.

Russ-eft \& Preskill (2005) note that part of the problem with adopting an ROI approach to HR measurement is a lack of construct definition, i.e. defining what constitutes an acceptable ROI from which to then identify appropriate quantitative or qualitative measures. We found that many managers appear to conceptually grasp the need to understand costs and benefits but, due to poor planning, they seldom articulate it in a formalized way. An additional problem seems to be the difficulties associated with adopting HR metrics and measurement processes in general (Russ-Eft \& Preskill, 2005; Wang et al., 2002). HR measures are particularly difficult to develop, implement and utilize in a population of employees such as expatriates, whose function and contribution within the firm often reaches far beyond a financial or quantitative cost-benefit calculation and instead to benefits that are predominantly nonquantifiable in nature (see Table 2 where 'long-term strategic' and 'individual' measures provide nonquantifiable examples of benefits to be expected from expatriates). As respondents in the study suggest, the challenge is even greater when the benefits expected of expatriates accrue over lengthy assignment periods of up to 3 or more years in duration.

The findings further show that few managers adopt an HR systems approach to manage their international assignment programs and instead focus on one or more individual HR functions, such as recruitment or compensation, to fulfill specific HR goals. Whilst we specifically focused our research on an HR systems approach in order to improve our understanding of expatriate ROI, we nonetheless found 
little support for this approach in practice ${ }^{2}$. Instead, we found that most managers are unable to adopt a HR systems approach because it is seen as a large and complex process of change in which existing mobility programs and policies would need to be significantly altered, and for which management support is unlikely to be forthcoming. This is despite managers' assertion (and evidence in our study) that a system of HR practices exists in principle, and despite managers' agreement that a HR systems approach can help foster a way of thinking that reduces some of the complexity of managing international assignments ${ }^{3}$. A significant problem is that most firms take a relatively short-term view of expatriate ROI: managers tend to assess more immediate and individual (employee) level outcomes up to two years post-assignment (e.g. repatriation turnover) to the exclusion of the intended longer-term strategic value expected from expatriates (e.g. long-term retention to enhance the transfer of cultural knowledge) and how that is linked to the firm's broader business objectives.

An additional problem seems to be the expectation of perfect rationality (i.e. that managers are always able to act in ways that maximize their utility and can choose the best possible action that is required). As noted by Holton and Naquin (2005) in their discussion of the link between bounded rationality and strategic decision making, managers typically work in fluid, complex, and dynamic environments where perfect rationality does not exist. Such environments may limit global manager's freedom, time and access to all the relevant information necessary to make effective decisions, such as developing and designing appropriate HR systems including appropriate measures. Under these circumstances managers may opt to use any number of ROI measures and HR practices that can produce acceptable, rather than optimal, outcomes. This can result in problems with internal alignment such as measures and practices competing with rather than complementing one another (Becker \& Gerhart, 1996) (see, for example, our finding that cost reduction strategies compete with talent management and retention initiatives). Whilst the goal of internal alignment from the perspective of expatriate ROI is not so much concerned with the HR practices themselves, but whether the practices have sufficient 'fit' to

\footnotetext{
${ }^{2}$ Only a small number of managers in the study ( $n=6,12$ percent) indicated that initiatives are currently underway to implement new expatriate ROI projects (see for example McNulty, 2008). These projects are intended to develop new or revised HR (and non-HR) systems approaches to global staffing which are aligned to the value and uniqueness of each firm's expatriate population.

${ }^{3}$ Managers who self-selected their participation in the study did so on the basis of obtaining the final report (offered in exchange for their participation) to assist them to improve their ROI practices. Interest in the need for a more effective approach to expatriate ROI was therefore very high.
} 
produce organizationally relevant outcomes (i.e. desired behaviours), we seldom found this to be the case in global firms. Instead, we found that most global managers work in environments in which there is likely to be limited information available, measurement criteria are often not agreed on, and time and resource constraints can limit a manager's ability to pursue an optimal alternative (Russ-Eft \& Preskill, 2005). Thus, in an environment where system components such as HR practices and other variables can not only function independently and interdependently but can also change as new strategies emerge, the context within which international assignments are managed becomes important. It may determine the extent to which expatriate ROI assessments are seen as necessary or irrelevant, appropriate ROI measures are developed and utilized on a consistent or adhoc basis, and an internally aligned HR systems approach is adopted.

We also found evidence that environmental and individual variables, such as location, motivation for undertaking an assignment, and organizational climate can impact ROI as much, if not more than, strategic alignment of HR practices towards mobility goals (Bowen \& Ostroff, 2004; Paauwe, 2004). We therefore conclude that a non-linear causal relationship often exists between strategy, HRM, and firm performance. Furthermore, if the non-linear nature of the relationships embedded in a HR system is poorly understood, it can lead to problems in attaining sufficient internal and external fit of the system as a whole. For example, we found that strategy does not always determine HRM practice and is instead often developed as a result of other factors including a firm's HRM practice. Such findings are particularly evident when expatriates are seen as a necessary cost of doing business globally in which case the adoption of HR practices is driven primarily by practical, rather than strategic, reasons. Such emerging strategies (i.e. strategies that are not pre-planned and emerge in response to a firm's change and growth) (Mintzberg, 2007) can have implications for the adoption of an effective HR system to manage expatriates. For example, carefully managed emergent strategies (regardless of the direction of the relationship) can foster higher levels of collaboration and organizational learning than strategies which are loose and unformulated in which there is little control and the strategy lacks logic. Our study shows that the subsequent effective or ineffective management of emergent strategies helps to explain why most managers report the inappropriate use of ROI methods and measures, and relatively few do 
not. Based on these findings, a HR systems approach that considers a non-linear relationship between strategy and HR practices (in which emergent strategies may exist) may produce more relevant organizational outcomes, particularly in recognizing that variables within the causal chain other than those attributable to the organization (e.g. employee or external variables) may also account for performance and organizational outcomes. The findings therefore support recent studies in which the relationship between strategy, HRM, and firm performance was found to be causally ambiguous (Rozhan, 1996; Wright, Gardner, Moynihan, \& Allen, 2005). On this basis, as Wright \& Haggerty (2004) assert, understanding the direction of the relationship between strategy, HRM and firm performance emerged as important in our study.

\section{Managerial implications}

When considering the implications of the findings for global firms as a whole, our analysis suggests that firms seeking to measure expatriate ROI and improve their rates of return should target three key areas. First, managers responsible for expatriates should define what expatriate ROI means (Russ-Eft \& Preskill, 2005) in terms of the reasons why they have a mobility program and use long-term expatriates. Of critical importance is the need for a paradigm shift from using only one measure to assess outcomes from all types of assignments to using a mix of measures that better suits the purpose of each type of assignment.

Second, managers responsible for expatriates must be able to identify the variables, and understand the independent and interdependent nature of the variables, that influence changes in rates of return, both internally and externally, in order to understand where lie the weaknesses and strengths in the fit of their international assignment processes and HR activities (Becker \& Gerhart, 1996). Two important variables identified in our study are organizational culture (see Table 3) and organizational structure (see Table 4). Consistent with these findings, we argue that the environment (context) in which global managers operates shapes and influences HRM processes in global firms, and in particular, the adoption of a HR systems approach towards the evaluation of effective international assignments and expatriate careers. For example, we found that organizational structures in which there is a tendency towards a strong operational (rather than strategic) focus in mobility planning and processes, and evidence of functional 
and organizational fragmentation (i.e. lack of co-ordination across functions and regions) (Toh et al., 2008), precludes the adoption of a HR systems approach to expatriate ROI. Consistent with Becker \& Gerhart (1996), the findings suggest an organizational inability to question, identify or legitimize the strategic changes required to implement a HR system that is both internally and externally aligned, or to recognize that a poorly aligned HR system needs to be revised, changed, removed or replaced. Such inertia may subsequently cause frictions, high transaction costs, and inefficient firm performance.

Third, our findings are consistent with research showing that the traditional model of expatriation is changing (see also Dickmann \& Harris, 2005; Lazarova \& Cerdin, 2007) with implications for global staffing initiatives. For example, long-term assignments are rapidly changing from full benefits packages, single-contract assignments, and guaranteed repatriation, to assignments where continuous mobility and re-assignment with reduced benefits is the acceptable norm. In conjunction with these changes, and in particular the increased use of local-plus and localization packages to minimize costs, the attractiveness of mobility for many employees is consequently reduced. In addition, and perhaps as a result of these changes, studies confirm that some expatriates are becoming less reliant on one firm for employment opportunities and are instead pursuing a 'boundaryless career' with multiple employers (Dickmann \& Harris, 2005). The implications for retaining global staff (and subsequent ROI) are significant, as the personal goals of expatriates may conflict with the needs and goals (strategic or practical) of the global firm (Suutari \& Brewster, 2003).

\section{Limitations}

We acknowledge that although our interview data provide only a single-rater response, validity and reliability concerns are addressed to some extent by using an inter-rater procedure to check for accuracy of the data collected and to limit researcher bias. We recognize that a range of functions and stakeholders would ideally need to be investigated in order to adopt a multilevel firm-wide systems approach (Bowen \& Ostroff, 2004; Wright \& Haggerty, 2004), which our paper does not directly consider. Future research from an HR systems perspective might also consider extending organizational outcomes expected from expatriates beyond only 'return on investment', to also understand how the effective management of international assignments and expatriate careers can impact a firm’s broader strategic goals, of which 
expatriate ROI may be one important component. Future research could also explore other types of assignments, including short-term and commuter, and the problems inherent in particular industries such as the energy sector which has predominantly a large population of career (re-assigned) expatriates.

\section{Conclusion}

The aims of this study are to extend understanding of expatriate ROI in global firms, to examine how ROI is measured and the barriers that may impede measurement, and to identify important variables likely to influence changes in ROI to the firm. The contribution of this study is threefold. It allows us to move beyond the conclusion that managers in global firms have difficulty measuring expatriate ROI, to also explain why it is viewed as difficult to measure. It extends the focus of expatriate ROI for long-term assignments beyond individual practices and outcomes to a system of HR practices that can more fully explain the internal and external variables (and the inter-relationships of the variables) likely to influence changes in expatriate ROI to the firm. In doing so, we are able to demonstrate how a systems framework can capture important financial and non-financial, and HR and non-HR, variables that conventional ROI accounting equations cannot encompass. We are also able to demonstrate using a deep qualitative study that an effective expatriate ROI framework is dependent upon a multivariate and nonlinear perspective, which constitutes an incremental but important step towards understanding the 'black box' between how HR practices utilized during expatriation may influence mobility outcomes as well as broader firm performance.

In addition, we are challenged to consider whether measuring expatriate ROI is actually a goal for managers in global firms, given the evidence which suggests that having expatriates is often a cost of doing business for which a formal measure may be unnecessary. Such a view challenges our thinking that measuring expatriate ROI may not answer all the questions we have about assessing the effectiveness of international assignments, and that global managers may not need to measure the return to justify continued investments in expensive mobility programs. An alternative view suggests that if international assignments are seen as a necessary cost of doing business for global firms, how expatriates are managed in terms of the HR practices that support their activities and how the outcomes of those activities impact broader business objectives may be far more important concerns (i.e. research question 
three). On this basis, our first and second research questions may, in fact, be moot in terms of further study which focuses only on how expatriate ROI is measured. We contend, based on our findings, that a more appropriate question is perhaps not to what extent global managers measure expatriate ROI, but how global firms evaluate the effective management of international assignments and expatriate careers, in which measuring expatriate ROI may be one important component. Our findings suggest that this may be a far more important question to pursue, given the complexity of the topic at hand and the rapidly changing nature of the traditional model of expatriation. Nonetheless, our study contributes a valuable first step towards understanding the phenomenon of expatriate ROI.

Overall, our research has enabled us to understand the conceptual and managerial issues related to global staffing and the critical issue faced by global firms in deploying key talent to fill positions in their headquarter and subsidiary operations. It has also provided evidence to suggest that the traditional model of expatriation is rapidly changing; and that our understanding of the HRM-firm performance link may require closer examination of non-strategic variables, with important implications for the management and retention of expatriate employees. It is noteworthy that our sample, including very well-known and 'sophisticated’ global firms, relies heavily on informal expatriate ROI practices that are predominantly used in spite of a broader global strategy, not because of it. Expatriate ROI therefore remains a challenging and complex process that IHRM managers are not yet well-equipped to address. We suggest that greater understanding of, and attention to, evaluating the effective management of international assignments and expatriate careers (including the measurement of expatriate ROI) will enhance both the credibility and the contribution of research and practice of global staffing initiatives in the international business community.

\section{References}

Becker, B. \& Gerhart. B., (1996). "The Impact of Human Resource Management on Organizational Performance: Progress and Prospects", Academy of Management Journal, 39, 779-801.

Beer, M., Spector, B. A., Lawrence, P. R., Mills, D. Q., \& Walton, R. E. (1984), Managing Human Assets, New York: The Free Press.

Bhaskar-Shrinivas, P., Harrison, D., Shaffer, M., \& Luk, D. (2005), "Input-based and Time-based Models of International Adjustment", Academy of Management Journal, 48, 257-281. 
Black, J. S., Gregersen, H. B., Mendenhall, M., \& Stroh, L. K. (1999), Globalizing People Through International Assignments, Reading, MA: Addison Wesley.

Boudreau, J. \& Ramstad, P., (2007), Beyond HR: The New Science of Human Capital, Boston, MA: Harvard Business School Press.

Bowen, D. \& Ostroff, C, (2004), "Understanding HRM-firm Performance Linkages: The Role of The 'Strength' of the HRM System", Academy of Management Review, 29, 203-221.

Caligiuri, P. \& Day, D., (2000), "Effects of Self-Monitoring on Technical, Contextual and Assignment-Specific Performance: A Study of Cross-National Work Performance Ratings." Group and Organization Management, 25, 154-174.

Collings, D., Scullion, H., \& Morley, M. (2007), "Changing Patterns of Global Staffing in the Multinational Enterprise: Challenges to the Conventional Expatriate Assignment and Emerging Alternatives", Journal of World Business, 42, 198-209.

Creswell, J. W. (1998), Qualitative Inquiry and Research Design: Choosing Among Five Traditions. Thousand Oaks, CA: Sage.

De Cieri, H. \& Dowling, P. (2006), "Strategic Human Resource Management in Multinational Enterprises: Developments and Directions", in Handbook of International HRM Research, eds. I. Bjorkman \& G. Stahl, Cheltenham, UK: Edward Elgar.

Denzin, N. \& Lincoln, Y., (2000). "The Discipline and Practice of Qualitative Research", in Handbook of Qualitative Research, eds. N. Denzin \& Y. Lincoln (2nd ed), Thousand Oaks, CA: Sage, 128.

Dickmann, M. \& Harris, H. (2005), "Developing Career Capital for Global Careers: The Role of International Assignments", Journal of World Business, 40, 399-408.

ECA International, (2007), Return on Investment Survey. London.

GMAC, (2005), Global Relocation Trends Survey. Woodridge, IL.

Goodwin, L. D. \& Goodwin, W. L., (1985), "Statistical Techniques in 'AERJ' Articles, 1979-1983: The Preparation of Graduate Students to Read the Educational Research Literature", Educational Researcher, 14, 5-11.

Huselid, M., (1995), "The Impact of Human Resource Management Practices on Turnover, Productivity, and Corporate Financial Performance", Academy of Management Journal, 38, 635-672.

Huselid, M., Jackson, S., \& Schuler, R., (1997), "Technical and Strategic Human Resource Management Effectiveness as Determinants of Firm Performance", Academy of Management Journal, 40, 171-188. 
Kast, F. \& Rosenzweig, J., (1973). "General Systems Theory: Applications for Organization and Management", Academy of Management Journal, 1, 447-465.

Kiessling, T. \& Harvey, M., (2005), "Strategic Global Human Resource Management Research in the Twenty-First Century: An Endorsement of the Mixed-Method Research Methodology", International Journal of Human Resource Management, 16, 22-45.

King, N., (1994), "The Qualitative Research Interview", in Qualitative Methods in Organizational Research: A Practical Guide, eds. C. Cassell \& G. Symon, London: Sage, 14-36.

Lazarova, M. \& Cerdin, J., (2007), "Revisiting Repatriation Concerns: Organizational Support Versus Career and Contextual Influences." Journal of International Business Studies, 38, 404-429.

McNulty, Y. (2008), "How a Major Multinational is Working to Overcome the Barriers to Improved Expatriate ROI", Global Business and Organizational Excellence, 27, 38-47.

McNulty, Y. \& Tharenou, P., (2004), "Expatriate Return on Investment: A Definition and Antecedents", Journal of International Studies of Management and Organization, 34, 68-95.

Miles, M. B. \& Huberman, A. M., (1994), Qualitative Data Analysis: An Expanded Sourcebook (2nd ed.), Thousand Oaks: Sage.

Mintzberg, H. (2007), "Towards a General Theory of Strategy Formation", in Tracking Strategies: Towards a General Theory, New York: Oxford University Press, 340-379.

Ostroff, C., (2000), Human Resource Management and Firm Performance: Practices, Systems, and Contingencies. Working Paper, Arizona State University.

Paauwe, J., (2004), HRM and Performance: Unique Approaches for Achieving Long Term Viability, Oxford, UK: Oxford University Press.

Paauwe, J. \& Boselie, P., (2005), "HRM and Performance: What Next?", Human Resource Management Journal, 15, 68-83.

Rozhan, B., (1996), "Strategic HRM: Evidence from the Irish Food Industry", Personnel Review, 25, 40-58.

Russ-Eft, D. \& Preskill, H., (2005), "In Search of the Holy Grail: Return on Investment Evaluation in Human Resource Development", Advances in Developing Human Resources, 7, 71-85.

Schmidt, S. \& Minssen, H., (2007), "Accounting for International Assignments: The Case of the German Chemical Industry." Journal of Human Resource Costing and Accounting 11, 214-228.

Scullion, H. \& Collings, D. (2006), Global Staffing, London: Routledge. 
Shaffer, M., Harrison, D., Gregersen, H., Black, J.S., \& Ferzandi, L., (2006), "You Can Take It With You: Individual Differences and Expatriate Effectiveness." Journal of Applied Psychology, 91, 109-125.

Suutari, V. \& Brewster, C., (2003), "Repatriation: Empirical Evidence from a Longitudinal Study of Careers and Expectations Among Finnish Expatriates", International Journal of Human Resource Management, 14, 1132-1151.

Takeuchi, R., Wang, M., \& Marinova, S., (2005), "Antecedents and Consequences of Psychological Workplace Strain During Expatriation: A Cross-Sectional and Longitudinal Investigation." Personnel Psychology, 58, 925-948.

Takeuchi, R., Yun, S., \& Tesluk, P., (2002), "An Examination of Crossover and Spillover Effects of Spousal and Expatriate Cross-Cultural Adjustment on Expatriate Outcomes." Journal of Applied Psychology, 87, 655-666.

Toh, S., Morgeson, F., \& Campion, M., (2008), "Human Resource Configurations: Investigating Fit With The Organizational Context." Journal of Applied Psychology, 93, 864-882.

Wang, G., Dou, Z., \& Li, N., (2002), "A Systems Approach to Measuring Return on Investment for HRD Interventions." Human Resource Development Quarterly, 13, 203-224.

Wright, P. \& Boswell, W., (2002), "Desegregating HRM: A Review and Synthesis of Micro and Macro Human Resource Management Research", Journal of Management, 28, 247-276.

Wright, P. \& Haggerty, J., (2004), "Missing Variables in Theories of Strategic Human Resource Management: Time, Cause, and Individuals", CAHRS/Cornell University Working Paper Series 05-03: Ithaca, NY.

Wright, P., Gardner, T., Moynihan, L., \& Allen, M., (2005), "The Relationship Between HR Practices and Firm Performance: Examining Causal Order", Personnel Psychology, 58, 409-446. 
Table 1. Sample characteristics

\begin{tabular}{|c|c|c|c|c|}
\hline & $n=51$ & $\%$ & & $n=51$ \\
\hline Industry & & & Number of Employees & \\
\hline Energy \& Utilities & & 15 & Less than 10,000 & 12 \\
\hline Financial Services & & 9.5 & 10,000 to 49,000 & 37 \\
\hline Computer Products \& Services & & 9.5 & 50,000 to 100,000 & 20 \\
\hline Banking & & 8 & More than 100,000 & 31 \\
\hline Consumer Products Manufacturers & & 8 & & \\
\hline Pharmaceuticals \& Healthcare & & 8 & Number of Expatriates & \\
\hline Business Services/Consulting & & 6 & Less than 100 & 8 \\
\hline Food and Beverages & & 6 & 101 to 500 & 57 \\
\hline Insurance & & 6 & 501 to 1,000 & 8 \\
\hline Aerospace \& Defense & & 4 & 1,001 to 5,000 & 19 \\
\hline Automotive \& Transport & & 4 & More than 5,000 & 8 \\
\hline Metals \& Mining & & 4 & & \\
\hline Chemicals & & 2 & Number of Long-Term Assignees & \\
\hline Electronics & & 2 & Less than 100 & 15 \\
\hline Industrial Manufacturing & & 2 & 101 to 500 & 57 \\
\hline Media & & 2 & 501 to 1,000 & 4 \\
\hline Telecommunications Services & & 2 & 1,001 to 5,000 & 20 \\
\hline Transportation Services & & 2 & More than 5,000 & 4 \\
\hline Company Type & & & $\underline{\text { Fortune } 500}$ & \\
\hline Public & & 80 & Yes & 63 \\
\hline Private / Private-Partnership & & 12 & No & 37 \\
\hline Subsidiary & & 4 & & \\
\hline Government & & 2 & & \\
\hline \multirow[t]{2}{*}{ Joint-Venture } & & 2 & $\underline{\text { Total No. Employees }}^{\mathbf{a}}$ & $3,762,400$ \\
\hline & & & Mean & 73,772 \\
\hline Company Structure & & & Lowest & 2,600 \\
\hline Global/MNC & & 94 & Highest & 346,000 \\
\hline \multirow[t]{2}{*}{ National } & & 6 & & \\
\hline & & & Total No. Expatriates $^{\text {ab }}$ & 76,676 \\
\hline Headquarters Location & & & Mean & 1,503 \\
\hline North America & & 51 & Lowest & 30 \\
\hline Europe & & 23 & Highest & 19,000 \\
\hline UK & & 12 & & \\
\hline Middle East \& Africa & & 6 & $\underline{\text { Total No. Long-Term Assignees }}^{\mathrm{a}}$ & 52,483 \\
\hline \multirow[t]{2}{*}{ Asia Pacific } & & 8 & Mean & 1,029 \\
\hline & & & Lowest & 15 \\
\hline Gender & & & Highest & 15,000 \\
\hline Female & & 56 & & \\
\hline Male & & 44 & & \\
\hline
\end{tabular}

Notes:

a These are employee numbers, not percentages

${ }^{\mathrm{b}}$ Expatriates include all types of assignee, i.e. long-term, short-term, one-way transfer and commuter 
Table 2. Informal expatriate ROI measures

\begin{tabular}{lll}
\hline Informal Measure & $\%$ & Evidence
\end{tabular}

\section{Approval purposes:}

Expected ROI is calculated in paper-only exercise as decision making tool

\section{Financial:}

Determine whether costs of assignment exceed budget or revenues increase

\section{Short-term functional:}

Immediate benefits assessed in local objectives met (e.g. knowledge transferred), local successor groomed, repatriation turnover, premature returns/failures, and so on

\section{Long-term strategic:}

Benefits assessed beyond end of assignment in long-term retention rates, promotion rates, talent management and succession planning objectives being sustained, building career expats, increasing brand recognition and relationships, and overall value gained

\section{Individual:}

Benefits accruing to expatriate employee rather than firm (e.g. career capital enhanced)
24 By the time we find someone who is going on an assignment it is a done deal. The estimate and the approval process is just a formality (FinanceCo3)

30 In terms of ROI ... we're able to determine it from apportioned revenue from the individual in what they charge ... it's relatively easy for us to determine how much somebody bills and offset that against assignment costs and look for baseline data to determine ROI (FinanceCo4)

41 It comes down to really the success in the assignment, are they actually doing the job ... it's got to be the fact that we increase sales by $\mathrm{X}$ or we design a new engine or we do whatever we needed to do ... the actual fundamental job you sent them to do (AutomotiveCo1)

31 We looked at our the profile of expats going out - psychometric profiles - and those returnees coming back ... it's very clear in which areas they have grown and developed and improved. So that to us is a return on our investment, on an unquantifiable side (EnergyCo5)

The return on investment would be that we continue to have a viable talent, whose talent is enhanced by the overseas experience ... somebody who is able to get the job done, but who is now more culturally savvy and can be counted on again for an assignment (AerospaceCo2)

12 Mobility has very much more to do with what is the net cash position going to be to the employee, and are we doing the right thing by the employee (FinanceCo3)

Note: Managers provided multiple responses, so percentages do not add up to 100 . 
Table 3. Barriers to measuring expatriate ROI

Operational Barriers

Software challenges

- Not enough functionality

- Not regionally accessible or usable

Structure of mobility program

- Continual reassignment

- Length of assignment unknown

- Decision by consensus (ROI difficult to implement)

- Lack of co-ordination between business units

- Strategic assignments (difficult to ascertain non-financial benefits)

- Working in teams (unable to ascertain individual benefits)

Lack of time/resources

Don't track data

\section{Cultural Barriers}

Lack of support/no buy-in

Expatriates cost of doing business

Financial 'boom' = less focus on ROI

\section{Strategic Barriers}

Lack of planning

- Unable to define or develop ROI measure

- Lack of accountability/ownership

Note: Managers provided multiple responses so percentages do not add up to 100 . 
Table 4. Variables influencing changes in expatriate ROI

\begin{tabular}{|c|c|c|c|}
\hline & $\%$ & & $\%$ \\
\hline Environment Variables & \multicolumn{2}{|r|}{ Organizational Variables cont'd } & \\
\hline Location of assignment & 18 & Compensation & \\
\hline \multirow[t]{2}{*}{ Currency fluctuations } & 4 & Aligning to performance & 30 \\
\hline & & Customizing packages & 26 \\
\hline Individual Variables & & Training \& Development & \\
\hline Re-assigned (career) expatriates & 22 & Cultural preparation & 12 \\
\hline Motivation for undertaking assignment & 18 & Non-work and Family Support & \\
\hline Personality and suitability & 14 & Offering support services & 32 \\
\hline Cultural adaptability & 10 & Performance Management & \\
\hline \multirow[t]{2}{*}{ Self-initiated moves } & 6 & Using data appropriately & 60 \\
\hline & & Customizing appraisals & 44 \\
\hline$\underline{\text { Organizational Variables }}$ & & Repatriation & \\
\hline HR Practices & & Career management & 36 \\
\hline Planning & & Planning repatriation & 32 \\
\hline Administrative: & & Identifying next role & 14 \\
\hline Budgeting and cost planning & 32 & Maintaining communication & 10 \\
\hline Approval procedures & 26 & Managing loss of benefits & 8 \\
\hline Tracking data, reporting trends & 16 & Leveraging experience & 6 \\
\hline Trimming benefits (cost cutting) & 14 & Mandating use of repatriation program & 4 \\
\hline Stealth expatriates & 4 & Retention & \\
\hline Strategic: & & Talent management & 66 \\
\hline Setting \& monitoring objectives & 78 & Loss during assignment & 16 \\
\hline Aligning mobility to firm strategy & 52 & & \\
\hline Ownership/accountability & 10 & Organizational Structure & \\
\hline Appropriate policy & 8 & Centralized vs decentralized & 14 \\
\hline Selection & & Joint venture, M\&A activity & 6 \\
\hline Quality of selection programs & 60 & & \\
\hline Choosing suitable candidates & 36 & & \\
\hline Attracting candidates & 20 & & \\
\hline Expatriate versus local & 18 & & \\
\hline Having a candidate pool & 18 & & \\
\hline
\end{tabular}

Note: Managers provided multiple responses so percentages do not add up to 100. 